\title{
Economic Impact of Four Cylinder Pedal Pump in a Selected Area of Bangladesh
}

\author{
Q. M. Alam* , R. ISlam AND M. A. B ASET \\ Agricultural Economics Division, Bangladesh Agricultural Research Institute, Gazipur, Bangladesh
}

Received 31 August 2005; received in revised form 17 May 2006; accepted 22 June 2006

\begin{abstract}
The study was conducted in Rajshai Barind area to know the short and long term impact of for cylinder manual (Pedal) Pump developed by Bangladesh Agricultural Research Institute. The Pump was dominated by small farmers who cultivated vegetables in homestead fallow land. Simple cost and return analysis indicated that the pump was profitable in the short-run. It was found that in both private and social point of view the pump was profitable and acceptable in the short run as well as in the long run. The command area of the pump was 0.20 ha. The pump was found underutilized. For full utilization of the pump, its operation should be extended to the main field where water source is available. Nevertheless, the pump is a substitute to modern irrigation system.
\end{abstract}

Key words: Pedal pump, irrigation, vegetable production.

\section{INTRODUCTION}

The development of Bangladesh agriculture is largely depend on the development of irrigation. Due to extreme scarcity of surface water and timely rainfall, vast tract of land remains uncropped or inadequately cropped during the year. Most of the crops are still grown under rainfed condition and naturally good harvest is uncertain.

Under the present circumstances and socio-agro-economic condition of the Bangladesh farmers and management problem of the large scale irrigation Bangladesh Agricultural Development Institute (BARI) developed Four Cylinder Pedal Pump (FCPP) suitable for small scale irrigation both for surface and ground water irrigation and serve as an important source of complementary irrigation through out the country. It is suitable as because the pump can be manufactured by locally available iron materials. The design is so simple that any local engineering workshop can easily fabricate. It is technically suitable and the price of the pump is within the affordable range of the poor farmers. One or two persons can operate it up to 15 minutes without rest. No risk is involved in adopting the technology and there is no adverse impact on environment. Given the advantages of this technology and the socioeconomic condition of Bangladesh, there might have great potentiality of this technology. It is urgent need to know the actual performance of this BARI technology. Therefore, a detailed socioeconomic impact study needs to be carried out before going for dissemination and suggestion for improvement and recommendation.

\footnotetext{
*Corresponding author: PSO, Agricultural Economics Division, BARI, Gazipur, Bangladesh. E-mail: quaziecon@yahoo.com

C) 2006, School of Agriculture and Rural Development, Bangladesh Open University. All rights reserved.
} 
Some studies were recently conducted on irrigation aspects in the Barind area. These are mostly cost and return analysis (BMDA, 1999; Haque and Khan; Hassan and Islam, 1997; Gafur and Latif, 1995). Since irrigation investment is the project type of investment, the present study used the discounted measures of project worth where the cost present study lies mostly with the methodological aspect.

\section{METHODOLOGY}

The study was conducted in Godagari upazila under Rajshahi Barind tract because BARI mostly supplied this irrigation technology in these areas. A formal field survey was conducted from 30 farmers using FCPP in this area. Another 30 non-users of FCPP were also being selected and interviewed. The field data for the study covered 2004-2005 kharif and Rabi seasons. Various books and reports were consulted to collect the necessary secondary information.

In accordance with the objective of the study 1. Enterprise costing/and 2. Discounted measures of project worth were used.

Benefits, costs and prices: In developing countries, pricing of cost and benefits items poses some problems due to market distortion. This problem can be solved using shadow price or accounting prices instead of ordinary market prices. Therefore, for economic analysis wherever necessary and possible ordinary market price was adjusted by using the suitable conversion factor. For financial analysis the prevailing market prices were used for the analysis and the pricing is not that difficult. In financial analysis out of pocket cost of the farmers was considered.

Investment cost: Investment cost included cost of purchasing the FCPP. Therefore, investment cost was involved with irrigation only.

Operation and maintenance cost: This cost was incurred for irrigation only and the following cost were included: Cost for making FCPP operational, labour cost for the operation of FCPP and labour and material costs for making pump house, cost for spare parts and repairing of pump.

Production costs: This cost was involved in connection with production with and without FCPP. The items included under this head were land preparation to harvesting and the primary processing in the production.

Quantification of benefits: Benefit (inflow) with and without project consisted of- With project: a) Gross value of production b) Salvage value; Without project: Gross value of production.

Salvage value: It was estimated the salvage value would roughly equal to 25 percent of the value of materials costs of FCPP.

Life of the project: Life of the project was assumed to be 10(ten) years.

Discount factor: The discount factor or the opportunity cost of capital was assured to be 15 per cent.

Cost of land: The farmers who were involved with irrigation had to forego the non-irrigated output from the same piece of land. This foregone output was the cost of land for those farmers who were presently associated with irrigation (for With project). This method was termed as very defensible (Gittinger, 1972).

Benefit-cost-ratio: Benefit cost ratio is defined as present worth of benefits divided by the Present worth of costs.

Internal Economic and Financial Return: Internal rate of return when used in economic analysis is termed as Internal Economic Return (IER) and when used for financial analysis, it is termed as Internal Financial Return (IFR). Internal rate of return can be calculated by using the formula as:

\begin{tabular}{|c|c|c|c|}
\hline & & & $\begin{array}{l}\text { Present worth of cash flow } \\
\text { at the lower discount rate }\end{array}$ \\
\hline $\begin{array}{l}\text { Lower discount } \\
\text { rate }\end{array}$ & 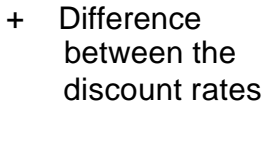 & $x$ & $\begin{array}{l}\text { Absolute difference between the } \\
\text { present worths of the cash } \\
\text { flow at the two discount rates }\end{array}$ \\
\hline
\end{tabular}


Depreciation: The FCPP is a simple device. Therefore, straight line method of calculating depreciation was used.

\section{RESULTS AND DISCUSSION}

Land area: Table 1 shows that average land area owned by FCPP growers was only 0.19 ha and that of homestead area of them was 0.05 ha. None of the farmers used their pump in the main agricultural field mainly because of lack of water sources. All the farmers in the study area used this pump for homestead (kharif and rabi seasons) vegetable production and they used $53 \%$ of their homestead area for this purpose. They introduced FCPP for last 3 years and engaged in irrigation as a whole for 4 years only.

Table 1. Size of holding of FCPP farmers

\begin{tabular}{ll}
\multicolumn{1}{c}{$\quad$ Items } & Land area \\
\hline \hline 1. Owned land area & 0.19 \\
2. Homestead are & 0.05 \\
3. Pond & 0.01 \\
4. Mortgage in land & 0.48 \\
5. FCPP* area & 0.03 \\
6. Number of years FCPP introduced & 3 \\
7. Number of year irrigation introduced & 4 \\
\hline
\end{tabular}

a. BARI four Cylinder Pedal Pump,

b. Fifty three percent of homestead area

Vegetable produced: In both the seasons viz. kharif and rabi. The kharif season vegetables grown were snake gourd, bitter gourd, read amaranthus, Indian spinach, okra green amaranthus, brinjal, gima kalmi and chilli. The rabi season vegetables grown were tomato, brinjal, radish, red amaranthus, spinach, chilli, cabbage, country bean, bottle gourd and green amaranthus.

Gross return: The gross return in the kharif season was Tk. 59546/ha and that in the rabi season was Tk 81817/ha. The rabi season gross return was 1.37 times higher over kharif season, because number of vegetables in the rabi season was higher and the farmers in this season realized a very high return from tomato alone. They also observed higher return from brinjal and chilli production as compared to these same vegetables in the kharif season. In both seasons the farmers earned Tk 141363/ha from vegetable production (Table 2).

Table 2. Gross income returns from different vegetable production with FCPP

(Taka/ha)

\begin{tabular}{|c|c|c|c|c|c|}
\hline \multicolumn{3}{|c|}{ Rabi season } & \multicolumn{3}{|c|}{ kharif season } \\
\hline \multicolumn{2}{|c|}{ Vegetables } & \multirow{2}{*}{$\begin{array}{c}\text { Gross return } \\
42321\end{array}$} & \multicolumn{2}{|c|}{ Vegetables } & \multirow{2}{*}{$\begin{array}{c}\text { Gross return } \\
10974\end{array}$} \\
\hline 1. & Tomato & & 1. & Snake gourd & \\
\hline 2. & Brinjal & 8179 & 2. & Bitter gourd & 1302 \\
\hline 3. & Radish & 6635 & 3. & Red amaranths & 2894 \\
\hline 4. & Red amaranthus & 2659 & 4. & Indian spinach & 10974 \\
\hline 5. & Spinach & 1742 & 5. & Okra & 10907 \\
\hline 6. & Chilli & 9748 & 6. & Green amaranths & 4537 \\
\hline 7. & Cabbage & 1193 & 7. & Brinjal & 7166 \\
\hline 8. & Country bean & 7598 & 8. & Gima kalmi & 6353 \\
\hline 9. & Bottle gourd & 1594 & 9. & Chilli & 4440 \\
\hline 10. & Green amaranths & 148 & & - & \\
\hline Toté & & 81817 & Tot & & 59546 \\
\hline
\end{tabular}

Both season Gross return $=(81817+59546=141363$ per ha $)$ 
Total Cost: The total cost in the kharif season was Tk 51048/ha in the kharif season and 64760/ha in the rabi season. Total (net) was 1.27 times higher in kharif season, mainly because the number of human labour for the operation of FCPP was higher in this season. Per ha cost in rabi season could have been much higher if the pump not being introduced and pump house was established in the kharif season. In calculating total cost, interest on operating cost was added to the total variable cost. Fixed cost was treated as annual capital cost for FCPP and worked out as depreciation cost for one year (Table 3).

\section{Table 3. Average cost of production with FCPP}

\begin{tabular}{|c|c|c|c|c|}
\hline & \multirow[t]{2}{*}{ Items } & \multicolumn{3}{|c|}{ Costs } \\
\hline & & Rabi season & Kharif season & Both season \\
\hline \multirow{9}{*}{1} & Variable cost & & & \\
\hline & Human labour & 48259 & 31826 & 80085 \\
\hline & Family & 36193 & 25461 & 61654 \\
\hline & Hired & 12066 & 6365 & 18431 \\
\hline & Draft power & 1977 & 3706 & 5683 \\
\hline & Material costs & 13852 & 12918 & 26770 \\
\hline & Total operating cost & 640088 & 48451 & 112539 \\
\hline & Interest on operating capital & 672 & 566 & 1238 \\
\hline & Total variable cost & 64760 & 49016 & 113776 \\
\hline \multirow[t]{4}{*}{2.} & Fixed cost & & & \\
\hline & Annual capital cost for FCPP & - & 2031 & 2031 \\
\hline & Total gross cost & 64760 & 51048 & 115808 \\
\hline & Total (Net) cost & 64760 & 51048 & 115808 \\
\hline
\end{tabular}

a. Command area 0.50 ha

b. Depreciation costs for pumps per year

Net return: Table 4 shows that return per ha was worked out as Tk. 8498 and Tk. 17057 in the kharif and rabi season respectively when full cost of human labour was considered. Net return in the rabi season in the case was found to be double than the kharif season. Net returns in both rabi and kharif seasons together was Tk. 25557/ha. While only higher human labour costs was considered rabi and kharif season net returns were Tk. 53250/ha and Tk. 33959/ha respectively. In this case rabi season net return was 1.57 times higher than that of kharif season. When added together the net return of both the seasons was Tk. 87209/ha considering higher laobur costs of human labour.

Table 4. Economic returns from different vegetable production with FCPP considering full labour costs, for family and hired labour

(Tk./ha)

\begin{tabular}{lccc}
\hline Items & Rabi season & Kharif season & Both season \\
\hline \hline Gross Return & 81817 & 59546 & 141363 \\
Total cost & 64760 & 51036 & 115796 \\
Net return & 17057 & 8498 & 25557 \\
\hline
\end{tabular}

Economic and financial analyses:_For analytical advantage the above cost and benefit items were further classified and adjusted in the following ways-

Investment costs: Table 5 presents the investment cost of the FCPP project from economic and financial points of analysis with a view to arriving at total investment cost. The material costs, local manufacturing cost, transport charges, manufacturers' profit, overhead etc. were computed separately and then added up together. These details were worked out for financial analysis. In economic analysis all these cost excepting the cost of skilled labour items could not be accepted as 
they were and thus corrected by applying appropriate conversion factors which was 0.60 and 0.67 for material costs of FCPP, and costs for overhead, transport and manufacturers' profit. Thus the investment costs for 1 ha of land were worked out as Tk. 7359 for economic analysis and 10946 for financial analysis.

Table 5. Investment cost estimate of BARI four cylinder pedal pump per unit

\begin{tabular}{llc}
\hline \multicolumn{2}{c}{ Total cost estimate of FCPP } \\
\hline \hline 1 & Total material cost & Estimated cost (Tk.) \\
2 & Labour cost & $1337.27^{\mathrm{a}}$ \\
3 & Overhead cost and transport & $300.00^{\mathrm{b}}$ \\
4 & Incidental expenses (10\% of A) & $75.0^{\mathrm{c}}$ \\
5 & Total cost (A+B+C+D) & $133.73^{\mathrm{d}}$ \\
6 & Manufacturer profit (20\% of E) & 1846.00 \\
\hline & Grand Total, Farm Gate Per unit (E+F) $=$ & $369.20^{\mathrm{e}}$ \\
\hline
\end{tabular}

Source: Adapted from cost estimated by farm Machinery and post harvest Process Engineering Division, BARI, Gazipur.

Note: ** Only in the case of economic analysis these figure (a,b, c, d and e) were multiplied by the planning commission conversion faced $0.60,1.0,0.67,67.0$ and 0.67 respectively to get the accounting price of machinery, skilled labour, overhead, transport and manufacturers profit. Thus, for economic analysis per unit of FCPP has calculated as Tk. 1489.

Operation and maintenance costs: This included the items like human labour costs, costs for changing of spare parts and repairing and costs for FCPP. For the purpose of economic analysis, human labour costs under this section was multiplied by the conversion factor $(0.50)$ for unskilled labour and the cost for spare parts and repairing was adjusted by the conversion factor 0.65 . Thus operation and maintenance costs for economic and financial analyses were calculate as Tk 22452/ha and Tk. 11129/ha for one crop year (Table 6).

Table 6. Operation and maintenance cost of per unit of FCPP for economic and financial analysis of the project

\begin{tabular}{llcc}
\hline \multicolumn{1}{c}{ Inputs } & & (Tk/ha) \\
\hline \hline 1. & Human labour for the Operation of FCPP & 21102 & 9706 \\
2. & Cost for Changing of spare parts and repairing & 114 & 188 \\
3. & Cost for FCPP house & 1236 & 1236 \\
\hline & Total & 22452 & 11130 \\
\hline
\end{tabular}

a. Human labours were multiply by planing commission convertion feature (.50) to get the accounting price of it.

b. Only hired labour costs were considered to get the out of pocket cost of the farmers

Production cost: The items included under this head were costs for land preparation to harvesting and primary processing of the vegetables. This is shown in Table 7. This cost was involved in producing both irrigated and non-irrigated vegetables. For economic analysis per ha production costs for irrigated vegetables were calculated as Tk. 49971/ha and 68911/ha respectively and that for non-irrigated vegetables were Tk. 17253/ha and 19526/ha respectively. For economic analysis production cost items at market price were adjusted where necessary particularly in the case of human labour to reflect the scarcity value of this item.

Gross value of production: Most of the vegetables produced were non-traded goods. Therefore, the question of the use of international price did not arise and market price of the vegetables produced were used both in the economic and financial analyses. Therefore, gross value of production (mentioned Table 4) hold good for both economic and financial analysis of the FCPP project. 
Table 7. Production cost of vegetables with FCPP

(Tk./ha)

\begin{tabular}{llcccc}
\hline \multirow{2}{*}{ Items } & \multicolumn{2}{c}{ Economic Analysis $^{\mathrm{a}}$} & \multicolumn{2}{c}{ Financial analysis $^{\mathrm{b}}$} \\
\cline { 3 - 6 } & & With project & Without project & With project & Without project $^{\mathrm{a}}$ \\
\hline \hline 1. & Human labour & 18940 & 2273 & $37880^{\mathrm{a}}$ & $4547^{\mathrm{a}}$ \\
2. & Draft Power & 5683 & 3410 & 5683 & 3410 \\
3. & Cost of inputs & 25348 & 11569 & 25348 & 11569 \\
\hline & Total & 49971 & 17252 & 68911 & 19526 \\
\hline
\end{tabular}

a. For economic analysis these figures are multiplied by planing commission conversion factor $(0.50)$ for unskilled labour.

Benefit cost ratio: Present worth of benefits and costs were calculated as Tk. 710049 and Tk. 602700 respectively at 15 per cent discount rate and the benefit cost ratio was calculated as 1.18 (Table 8). It was found that benefit cost ratio was more than 1 (one) which indicated that the FCPP project was acceptable from economic point of view. Internal rate of return was found to be more than 50 percent in both economic and financial analyses which indicated that FCPP project was profitable both from the society and farmer's point of view (Table 8 and 9 ).

Table 8. Economic analysis ${ }^{a}$ of the four cylinder pedal pump irrigation project (Considering 50 percent labour scarcity)

\begin{tabular}{|c|c|c|c|c|c|c|c|c|}
\hline \multirow{3}{*}{\multicolumn{2}{|c|}{ Items }} & \multirow{3}{*}{$\begin{array}{l}\text { Without } \\
\text { project }\end{array}$} & \multicolumn{5}{|c|}{ With Project (FCPP) } & \multirow{3}{*}{ Total } \\
\hline & & & \multicolumn{5}{|c|}{ Years } & \\
\hline & & & 1 & 2 & 3 & $4-9$ & 10 & \\
\hline \multirow[t]{4}{*}{1.} & Inflow & & & & & & & \\
\hline & A. Gross value of production & 63613 & 141363 & 141363 & 141363 & 141363 & 141363 & \\
\hline & B. Salvage value & & & & & & 1653 & \\
\hline & Total & 63613 & 141363 & 141363 & 141363 & 141363 & 143016 & \\
\hline
\end{tabular}

2. Outflow
A. Investment cost
- $\quad 7359$

B. Operation \& maintenance cost

C. Production cost

22452

22452

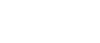

$22452 \quad 22452$

\begin{tabular}{lc}
\hline \multicolumn{1}{c}{ Total } \\
\hline $3 . \quad$ Net benefit without project
\end{tabular}

17253

49971

49971

49971

49971

49971

17253

$79781 \quad 72423$

$\begin{array}{lll}72423 & 72423 & 72423\end{array}$

4. Total cost due to project

4636146361

46361

126130

118

18783

46361

15221

5. Incremental benefit

6. D. F. $15 \%$

7. Present worth of gross benefit

0.870

22580

118783

4636

46361 at $15 \%$ discount rate

8. present north of gross cost at $15 \%$ discount rate

$\begin{array}{ll}- & 1522 \\ - & 0.87\end{array}$

- 12298

0.756

22580

118783

118783

D. F. $50 \%$

10. Present north of incremental benefit at $50 \%$

Note: B.C.R $=\frac{710049}{602700}=1.18$ (Approximately) $:$ IER is greater $\tan 50 \%$

B.C.R = Benefit-Cost Ratio

IER= Internal Economic Return

a Analysis was made one per ha basis 
Table 9. Financial analysis ${ }^{a}$ of the four cylinder pedal pump irrigation project (Considering hired labour only)

\begin{tabular}{|c|c|c|c|c|c|c|c|c|}
\hline \multirow{3}{*}{\multicolumn{2}{|c|}{ Items }} & \multirow{3}{*}{$\begin{array}{l}\text { Without } \\
\text { project }\end{array}$} & \multicolumn{5}{|c|}{ With Project (FCPP) } & \multirow{3}{*}{ Total } \\
\hline & & & \multicolumn{5}{|c|}{ Years } & \\
\hline & & & 1 & 2 & 3 & $4-9$ & 10 & \\
\hline \multirow[t]{4}{*}{1.} & Inflow & & & & & & & \\
\hline & A. Gross value of production & 63613 & 141363 & 141363 & 141363 & 141363 & 141363 & \\
\hline & B. Salvage value & - & - & - & - & - & 1653 & \\
\hline & Total & 63613 & 141363 & 141363 & 141363 & 141363 & 143016 & \\
\hline \multirow[t]{5}{*}{2.} & Outflow & & & & & & & \\
\hline & A. Investment cost & - & 10946 & - & - & - & - & \\
\hline & B. Operation \& maintenance cost & - & 11129 & 11129 & 11129 & 11129 & 11129 & \\
\hline & C. Production cost & 19526 & 68911 & 68911 & 68911 & 68911 & 68911 & \\
\hline & Total & 19526 & 90987 & 80041 & 80041 & 80041 & 80041 & \\
\hline 3. & Net benefit & 44088 & 50376 & 61323 & 61323 & 61323 & 62976 & \\
\hline 4. & Total cost without project & 44088 & 44088 & 44088 & 44088 & 44088 & 44088 & \\
\hline 5. & Incremental benefit & - & 6289 & 17235 & 17235 & 17235 & 18888 & \\
\hline 6. & D. F. $50 \%$ & - & 0.667 & 0.444 & 0.296 & 0.541 & 0.017 & \\
\hline 7. & $\begin{array}{l}\text { Present north of incremental } \\
\text { benefit at } 50 \%\end{array}$ & - & 4196 & 7653 & 5103 & 9323 & 321 & 26596 \\
\hline
\end{tabular}

\section{CONCLUSION}

FCPP increased farmers' productivity, farm income and employment in small farm condition of very small farm condition. It effectively utilized the family labour. It increased vegetable production and consumption Other than homestead area farmers were not interested to use FCPP because near the main field ponds were not available. Also availability of irrigation through underground water source may not be technically feasible in the barind area by this method ( FCPP can use both surface and ground water for irrigation).

\section{LITERATURE CITED}

BBS. 2002. Statistical Year Book of Bangladesh. Bangladesh Bureau of Statistics, Statistics Division, Ministry of Planning, Government of the People's Republic of Bangladesh, Dhaka, Bangladesh.

BMDA. 1999. Progress Report. Barind Multipurpose Development Authority, Rajshahi, Ministry of Agriculture, Government of the peoples' Republic of Bangladesh, Dhaka, Bangladesh.

FFYP. 1998. The Fifth Five Year Plan. Ministry of Planning, Government of the People's Republic of Bangladesh, Dhaka, Bangladesh.

Ghafur, A. and Latif, A. 1995. Barind Integrated Area Development Project: An Evaluation. The Bangladesh Development Studies, Agargaon, Dhaka-1207, Bangladesh.

Gittinger. J, 1992. Economic Analysis of Agricultural Project Washington. The Economic Development Institute, Institutional Bank for Reconstruction and Devlopment, 1972.

Haque. M. A. and Khan, M. H. 1999. Impact of Barind Multipurpose Development Project on Socioeconomic Development in Rajshahi Region. Bangladesh Journal of Training and Development 12(1\&2), 25-31.

Hassan, M. N. and Islam, M. N. 1997. Water Utilization under different Deeptubewell Management in Barind Area of Bangladesh. Bangladesh Journal of Water Research 14-18, 10-19. 